http://dx.doi.org/10.4314/jae.v15i1.10

\title{
Critical Challenges of Pre and Post Service Extension Education and Training in Nigeria
}

\author{
Nzeribe, T. A. K \\ Department of Agric Education, \\ Federal College of Education (Tech.), Umunze \\ E-mail address:- nzetangee009@yahoo.com
}

\begin{abstract}
The challenges of extension education and training in Nigeria are inherent in the nature and characteristics of the extensionist himself, the trainers, training needs and the ability of the training institutions and agencies to develop and deliver appropriate training programmes relevant to the system. The demand for functional pre and post service extension education in Nigeria is deeply rooted in the level of technological complexity of modern society. Extension education and training are geared towards achieving functional change in behaviour. Actualizing this purpose is faced with a myriad of challenges including the turbulent and unstable Nigerian political system, misplaced priorities, poor policy decision and implementation, rapid development in science and technology, dearth of facilities and infrastructure in extension education and training institutions, poor funding and its adverse consequences and problems associated with information/communication technologies access and utilization. Contemporary education and training programmes in the extension system should clearly address these challenges. This paper recommends solutions to the challenges vis-à-vis keeping pace with the rate of the world's technological/agricultural development.
\end{abstract}

Keywords: Critical challenges, extension education, training.

\section{INTRODUCTION}

It has been noted that Nigeria's ability to realize her vision of becoming one of the twenty largest economies in the world by the 2020 is largely dependent on her capacity to transform her population into highly skilled citizens capable of competing globally. The education sector is consequently pivotal to the actualization of this dream. Education and teaching are pre-requisite for learning and effective performance in extension. Asiabaka (2002) states that learning means change in behaviour of the learner which can manifest in the cognitive, affective and psychomotor domains. Accordingly, he distinguishes education from training and emphasizes that education connotes knowledge of both theory and practice while training has to do more with practice. Extension training and 
education take two major dimensions: pre-service and post service. While preservice education and training are obtained in a formal school, college or university set-up, post service education and training are planned to fill a skill-gap, improve upon the pre-service training and usually received on the job.

F.A.O. (1985) emphasizes that educational programmes must form an integral part of all rural development activities and that success of such development efforts depends in many instances on the availability of enough agriculturally trained personnel of adequate quality, hence lbenta (2007) opined that the major policy objectives of any government is to increase food production, raw materials and exportable cash crops to improve the employment opportunities and income of the populace. The need for employment reduction, poverty alleviation and wealth creation advocates proper training for extension staff who will subsequently transform our rural populace for greater productivity and increased income.

Agricultural colleges, polytechnics and colleges of education provide intermediate level education for extension while high level extension education is provided at the universities. Pre-service education and training at various levels are needed by extension for competency development. These competencies are needed in technical subject matter (crop, soil, animal); socio-cultural make-up of clientele, communication skills and programme planning and evaluation. Post service training is required to keep staff abreast with the latest research findings and technologies, increase their knowledge base of subject matter, and cross pollination of ideas and experiences (Asiabaka 2002).

\section{Challenges of Extension Education and Training}

1. The Nigerian political system: The greatest challenge of pre and post extension education and training in Nigeria is the political system. The system has the following faulty features:

- $\quad$ The system is unstable, turbulent, selfish, corrupt, infested with chronic and deeply rooted tribalism, nepotism, unpatriotism and sectionalism. Presently, cultism is seriously attacking the system (Uzoagulu 2009)

- $\quad$ The system seems to seek the welfare of the players more than that of the citizens. The political interest overrides any other interest no matter the intensity and importance. This is why the system considered N5m a year as adequate for a university professor, whereas a senator, a minister or a commissioner may use $\mathrm{N} 10 \mathrm{~m}$ to furnish his or her house. His or her salary is another matter that needs not be mentioned here.

$>\quad$ The political system is immature, weak and loose. The players are unstable and terribly political. The system, by the action of the players does not allow adequate fund to be provided for skill development. Funds may be placed in the system but only small amount may be devoted for equipping people with the right skills for living.

$>$ Misplaced priority of the players of the system is obvious. The political party determines priority not the citizen's needs. A state governor may 
have good educational projects for his people, but the political party or other interested parties may stop him from reaching the people through the intended project. Priorities sometimes are not observed in the system. Sometimes, policies, decisions and implementation are not people-oriented but on very parochial and selfish interests.

2. Rapid advancement in science and technology: The rate at which technology and science are developing and advancing is astronomical. It would appear that such rate seems too fast for the developing countries like Nigeria. While we are still battling with technology developed in 1960s and would not understand the recent technology of 2009, by the time we arrive at the technology of 2009, the developed countries would have also advanced and that would be about the year 2030. There is doubt whether Nigeria will ever catch up with the rest of the world in science and technology. Our major delay and concern however is corruption, not the people (brain) or the scientific and technological will. It is unfortunate that corruption has been institutionalized in this country. Skill development in Nigeria can generally be described as very slow, undynamic, (unscientific and unprogressive) and unhealthy. The skill development processes are very slow because there is little interest; it is undynamic since it is not pursued with vigour and focus; it is unscientific and unprogressive because improvement is not sought for through research; and it is generally unhealthy (it is sick) because objective assessment is not carried out and when it is carried out the remedies or cue are simply on the lips of the leaders and not implemented (Uzuagulu, 2009).

3. Teacher factor: The poor preparations of teachers at some tertiary institutions have resulted in the production of poor quality graduates. Many teachers cannot organize laboratory practicals that will create opportunities for learners to acquire requisite skills. This may possibly be due to insufficient exposure to science content and processes during the training period. It is important to note that teachers cannot promote learning beyond their own knowledge, because nobody can give what he/she does not have. Research results also indicate that the quality of teaching makes a difference in students learning, (Ball \& Bass 2000).

Many teachers still use obsolete methods of teaching - namely lecture method, demonstration method and reading from text books. Practical lessons are rarely organized, either due to lack of facilities or due to the teacher's incompetence. Field trips and excursions are never mentioned. Amidst all these, there is generally a lack of commitment on the part of many teachers, at the tertiary and basic levels of the education system, resulting in the graduation of half baked graduates and extensionists.

4. The dearth of facilities and infrastructure in institutions: Infrastructure and facilities for education in the country is grossly inadequate. Laboratories, libraries, workshops are in short supply and generally illequipped. The colleges and Universities do not even boast of adequately 
equipped laboratories. Overcrowded classrooms/laboratories, and high student-teacher ratio are re-occurring features in the schools. The dearth of technical staff to man the existing laboratories puts more strain on the science teacher and reduces his output and effectiveness. (Warra et. al 2009). About $15 \%-50 \%$ of infrastructure, equipment and books are nonfunctional, obsolete or dilapidated. These have obvious consequences on the educational and training outcomes.

5. Insufficient time to complete prepared learning modules: The Nigerian educational system has experienced a lot of strike actions by both staff and students. This normally disrupts the school calendar resulting in insufficient time to complete the learning modules prepared by the teachers. Most often the semester examinations are usually scheduled two or three weeks after resumption from a protracted strike leaving most of the content untaught.

6. Information and communication technologies (ICT): One of the challenges that have been identified is the teacher's phobia for computers. The modern global trend is the use of information communication technologies in the effective implementation of the educational system programme, it is the reservoir of knowledge and provides functional materials for research. At present administrators/teachers are less prepared for the use of information communication technologies in the classrooms and for research purposes (Ivowi 1998 and Mezieobi 2006). Some are yet to be sufficiently skilled in the use of ICTs.

Oladosu (2005) found that only $7 \%$ of extension agents use ICT regularly and only $20 \%$ of extension agents claimed to be able to use the CD Rom for information management. This is why Ulijekoon and Newton (2000) argued that without appropriate grounding in communication skills, the technical assets of training programs can quickly become ineffectual. Nigeria is experiencing a severe shortage of ICT skills and personnel necessary for taking advantage of new and emerging technologies in the knowledge society. This is compounded by a weak ICT backbone in the country, poor and expensive bandwidth provision as well as poor and obsolete ICT infrastructure and services in the educational system. Other challenges include:

- inadequacy of qualified ICT teachers and other ICT personnel;

- low retention of ICT staff;

- low ICT and ICT related research;

- inadequate funding of ICT for development and deployment as well as implementation of problems of power and energy (FME,2009).

7. Funding: The tertiary institutions draw a significant part of their funds from the proprietors (Federal Government, State Governments and Private proprietors) while the remaining part is internally generated from levies/charges/fees (for Private Institutions), international development partners, support from alumni associations, and linkages with industries in 
Nigeria and abroad. Over the years, funding of tertiary education has not been adequate because the allocation from the proprietors fall short of what is actually required. For example in 2004, Federal Government released only $24.7 \%$ the budget request from the universities (FME,2009). This has hampered education delivery, monitoring, inspection and other quality. Extension education and training is not left out in this handicap.

\section{Strategies for Tackling the Challenges}

1. Building capacity of officials responsible for policy formulation and implementation and re-orienting the populace towards a patriotic spirit and love for the country rather than self.

2. Expanding and improving the facilities (physical and instructional) and replacement of obsolete equipment in the existing tertiary institutions. This will make them more relevant and globally competitive. There is urgent need for improvement in the general funding of such institutions.

3. Promote private sector and state government participation in the provision of tertiary education especially extension education. This will include increasing awareness and support for alternative route to higher education through innovation enterprise institutions (IEI). A need to develop a core of policy makers, extension programme planners and technical specialists as been emphasized (Asiabaka, 2002).

4. There is a need to develop a highly technical extension training system for information and communication technology. This is to face the future anticipated better educated farmers who are expected to be information seekers.

5. Strengthening linkages between foreign tertiary institutions and their Nigerian counterparts for the purpose of reinforcing capacity building on the part of lecturers, in extension.

6. Creating synergy between tertiary institutions and the organized private sector since the provision of ideal extension education cannot be left in the hand of government alone. Asiabaka (2002) recommended the involvement of private extension service providers such as multinational campaigns and non-governmental organizations (NGOs.) in funding such institutions. If Extension services are privatized to become demand-driven, accountable, efficient, decentralized in coordination. This will help to inject new blood in the area of pre- and post service training and education in extension service.

7. Enhancement in the condition of services of tertiary institutions staff to avoid increase strike and disruption of academic programs. This will also attract and enhance retention of quality academic staff to the institutions.

8. Increase in budgetary provision to Extension training institution. This will also include enhancement of ICT development and deployment and integration of ICT in extension training curriculum. 


\section{CONCLUSION}

Agricultural extension plays a crucial role in the economic and social development of developing countries such as Nigeria. For extension to play this role properly, extensionists should be properly equipped in the various educational and training institutions. III-equipped extension staff cannot deliver much since extensionists cannot extend beyond their level of knowledge during their days in the training institutions. To attain perfection in agricultural productivity via extension our educational and training institutions should be fully empowered in human and material resources, adequately funded, ICT - driven and have a proper-linkage with developed economies. This will help to reduce poverty, hunger and attain state of perfection in our agricultural output and Nigerian economy generally.

\section{REFERENCES}

Asilabaka, C.C. (2002). Agricultural Extension: A handbook for development practitioners. Omoku, Molsyfem Publishers.

Balls and Bass, (2000). Interweaving content and pedagogy in teaching and hearing mathematics. In J. Boaler (ed) Multiplier perspective on the teaching and learning of mathematics, Wespart, CT Atblex publishers.

Food and Agricultural Organization (FAO) (1985). The management of agricultural schools and colleges. World conference on Agrarian Reform and Rural Development Report.

Federal Ministry of Education (2009). Road map to Nigerian Education (consultative Draft).

Ibenta, S.N. (2007). Starting and managing your own business. Paper presented at a workshop on NHIS/Retirement plan for workers at FCE(T) Umunze. March, 26-27.

Ivowi, U.M.O. (1997). Science Education in Nigeria. A publication of National Academy of Education.

Newton, B. (2000). Multimedia support for extension trainers in developing countries. CESO Report. 20: 14-18.

Oladosu, I.O. (2005). Extension workers ICT use characteristics and training needs for the sustainability of rural development and extension training in Nigeria. Proceedings of $10^{\text {th }}$ AESON Annual National Conference.

Uzuagulu, A.E. (2009) Skill development in vocational and technology education: proceedings of $9^{\text {th }}$ National conference on STE for the millennium Development Goals FCE(T) Umunze (22-25 ${ }^{\text {th }}$ September).

Warra, A.A, Utoro, S.S. and Babayemi, A.W (2009). Factors affecting students performance in Paul Eniyelu (ed) Meeting challenges to sustainable development through science and technology. Proceedings of ICASE Regional conference Abuja 2009. 